Japan. J. Med. Sci. Biol., 19, 293-303, 1966

\title{
BIOCHEMICAL AND HISTOPATHOLOGICAL STUDIES ON THE TUMOR-DEVELOPING LIVERS OF MICE FED ON THE DIETS CONTAINING LUTEOSKYRIN*
}

\author{
NOBUICHI MOROOKA, NAOKO NAKANO \\ Department of Food Research, \\ AND NOBUYUKI UCHIDA \\ Department of Pathology, National Institute of Health, Tokyo
}

(Received: September 14th, 1966)

\begin{abstract}
Histopathological changes termed by us as "carbohydrate-food type degeneration" developed in the liver of mice when fed for a short period on semisynthetic diets containing rice as the main carbohydrate source even though the diet was supplemented with $23 \%$ casein.

When luteoskyrin, a toxic pigment from $P$. islandicum Sopp was added to these diets, necrosis developed in the liver resulting in tumor formation in the tissues adjacent to these necrotic lesions. The acid soluble sulfer contents in the liver increased in association with the occurrence of degeneration of the liver. The change may be an expression of abnormal metabolism in the liver.
\end{abstract}

\section{INTRODUCTION}

Kobayashi et al. (1959) found that the rats fed on ground moulded rice (in 2 ulated with $P$. islandicum) for a considerable period developed primary hepatic carcinoma. Morooka et al. (1964a) reported that mice of the DD strain fed on a low protein diet consisting of polished rice as the basic component and luteoskyrin, a toxic pigment from P. islandicum (Shibata, Takido and Nakajima, 1955; Shibata and Kitagawa, 1956 ; Morooka, 1956), at a concentration of $5 \mathrm{mg} \%$ developed hepatic tumor at a frequency of $50 \%$. Then, the same authors studied changes in the activities of some hepatic enzymes during the formation of tumor in the liver, and found a markedly reduced activity of cysteine desulfhydrase among the mouse groups fed on the luteoskyrin diets (Morooka et al., 1964b).

In the present study, changes in the amount of intracellular sulfur compounds in the liver of the mice during the period of developing hepatic tumor was examined. The diets added with luteoskyrin caused an increase in the amount of the total sulfur and the acid soluble sulfur in the liver in association with development of necrosis.

\footnotetext{
* Presented at the 24th Annual Meeting of the Japanese Cancer Association, Fukuoka, Japan, Oct. 1965.

諸岡 信一・中野 尚子(国立予防衛生研究所食品衛生部)

内田 信之 (国立予防衛生研究所病理部)
} 


\section{Materials AND Methods}

1. Luteoskyrin: Luteoskyrin was purified from dried mycelial mass of P. islandicum according to Morooka (1956).

2. Experimental animals: Male white mice, 4-week-old, weighing $15-20 \mathrm{~g}$ of the DDD strain (established by the Institute of Infectious Diseases, the University of Tokyo, from the DD stock) and the DDS strain were used. Mice of each strain were allotted at random to each feeding group.

3. Basic diets: The ingredients of Diet I were similar to those of the mouse pellet of "Purina" Corp. Diets II and III were prepared according to the recipe described by Pecora and Hundley (1951) and composed of white rice, the inorganic salt mixture, the vitamine mixture, corn oil, cholin and milk casein. Diet II contained casein at $3 \%$ and Diet III at $23 \%$. The protein content of Diet III was similar to Diet I. Diet II served as a low protein diet. The amino acid composition of each diet is shown in Table 1.

Table 1. Amino acid composition of experimental diets

\begin{tabular}{lccc}
\hline & & Diet & \\
\cline { 2 - 4 } Amino Acid & I & II & III \\
\cline { 2 - 4 } Alanine & $1.44 \%$ & $0.41 \%$ & $0.92 \%$ \\
Arginine & 1.55 & 0.45 & 1.08 \\
Aspartic Acid & 2.57 & 0.72 & 1.88 \\
Cystine & 0.15 & 0.06 & 0.12 \\
Glutamic Acid & 3.82 & 1.47 & 1.14 \\
Glycine & 1.38 & 0.30 & 0.59 \\
Histidine & 0.58 & 0.19 & 0.69 \\
Isoleucine & 1.34 & 0.39 & 1.48 \\
Leucine & 2.25 & 0.70 & 2.35 \\
Lysine & 2.05 & 0.42 & 1.76 \\
Methionine & 0.59 & 0.19 & 0.70 \\
Phenyl Alanine & 1.32 & 0.39 & 1.27 \\
Proline & 2.03 & 0.55 & 2.54 \\
Serine & 1.80 & 0.43 & 1.52 \\
Threonine & 1.32 & 0.34 & 1.03 \\
Tryptophan & 0.01 & 0.11 & 0.32 \\
Tyrosine & 0.37 & 0.27 & 1.26 \\
Valine & 1.62 & 0.54 & 1.74 \\
\hline Total & 26.19 & 7.93 & 22.39 \\
\hline
\end{tabular}

4. Addition of luteoskyrin: Luteoskyrin was added at $5 \mathrm{mg} \%$ to Diets $\mathrm{I}$, II and III (designated as Diets I-L, II-L and III-L, respectively).

5. Feeding method: At least 10 mice of each strain were fed with one of the six diets. For short-term feeding, 5 mice were housed in one cage ; for long-term feeding, each mouse was housed in one cage. The animals were fed with diet and water ad 
libitum during a 7-day preliminary feeding before the luteoskyrin feeding periods.

6. Items for examination: The mice were examined on the 15, 30, 90 and 180th days of feeding for the following items : 1) body weight, 2) liver weight, 3) liver protein, 4) sulfur contents of the liver, (a) total sulfur (TS), (b) acid soluble sulfur (ASS) and (c) acid insoluble sulfur (ISS) and 5) histopathological changes in the liver.

7. Determination of protein and sulfur contents in the liver: 1) Materials; The mice were sacrificed by decapitation during 10:00-11:00 a. m. on the indicated days (Calcutt, 1964). After bleeding, the liver was removed, washed with cold saline, and weighed. A portion of the liver at a fixed position was taken for histopathological examination. The remainder was cut up, frozen in a acetone-dry ice mixture and homogenized for $3 \mathrm{~min}$ by adding 4 volumes of $0.017 \mathrm{M}$ phosphate buffer ( $\mathrm{pH} 7.0$ ) in a Potter-type homogenizer.

2) Protein content of the liver; The amount of protein was determined by the method of Lowry et al. (1951).

3) Sulfur contents ;

a. Total sulfur (TS): A 2-ml portion of liver homogenate was mixed with $3.0 \mathrm{ml}$ of $2 \% \mathrm{HPO}_{3}, 0.2 \mathrm{~g}$ of zinc powder and $4.0 \mathrm{ml}$ of a saturated ammonium sulfate solution. The mixture was boiled for $15 \mathrm{~min}$ and centrifuged at $3,000 \mathrm{rpm}$ for $5 \mathrm{~min}$. The precipitate was washed twice with $2 \% \mathrm{HPO}_{3}$. The supernatant and the washings were combined and the total volume was made up to $10.0 \mathrm{ml}$. To $5 \mathrm{ml}$ of the extract, 10 $\mathrm{mg} \%$ solution of 2,6 dichlorophenol indophenol was added dropwise to an end point giving a light pink color to eliminate such reducing substances as ascorbic acid. The total sulfur was titrated with $10^{-4} \mathrm{M} \mathrm{KIO}_{3}$ at $0 \mathrm{C}$ after adding $1.0 \mathrm{ml}$ of $5 \% \mathrm{KI}$ and 2 drops of $1 \%$ soluble starch (Kuroiwa, 1959) and expressed in equivalent glutathione per gram of wet liver.

b. Acid soluble sulfur (ASS): To $2 \mathrm{ml}$ of the liver homogenate, about $5 \mathrm{ml}$ of cold $5 \%$ TCA was added. The mixture was centrifuged at $3,000 \mathrm{rpm}$ for $10 \mathrm{~min}$ at $0 \mathrm{C}$. The supernatant was transferred to a $10 \mathrm{ml}$ of volumetric flask. This procedure was repeated 3 times. The extracts were combined and made up to $10.0 \mathrm{ml}$. To a $2-\mathrm{ml}$ portion of the combined extract, 2,6 dichlorophenol indophenol was added dropwise as described above. ASS was titrated with $10^{-4} \mathrm{M} \mathrm{KIO}_{3}$ and expressed in equivalent glutathione (Kuroiwa, 1959).

c. Acid insoluble sulfur (ISS): The liver homogenate was diluted 20-fold with water, to one $\mathrm{ml}$ of which was added $9 \mathrm{ml}$ of $0.06 \mathrm{M}$ hydrochloric acid-acetone. The precipitate was centrifuged and washed 3 times with acetone to remove excess hydrochloric acid. An acetone solution of mercury orange (Dajac Laboratories, Borden Chemicals Co.) was added to the precipitate. The mercury orange bound to protein was released with hydrochloric acid-acetone and measured at $470 \mathrm{~m} \mu$ in a Beckmann spectrophotometer (Sakai and Dan, 1959 ; Sakai, 1960 ; Bennett and Watts, 1958).

\section{RESULTS}

\section{Influence of the Basic Diet Constituents}

\section{1) Body weight, liver weight and liver protein.}

The influences of different diets were recognized from the early stage of the feeding period. The extent of the influence was dependent upon the protein content of the diet. In the later stage, however, the differences became smaller (Table 2). 
Table 2. Effect of experimental diet on the contents of glutathione

\begin{tabular}{|c|c|c|c|c|}
\hline $\begin{array}{c}\text { Group* } \\
\text { (Diet) }\end{array}$ & $\begin{array}{l}\text { No. of } \\
\text { mice }\end{array}$ & $\begin{array}{l}\text { Feeding } \\
\text { period (day) }\end{array}$ & State of liver & $\begin{array}{l}\text { Body wt } \\
(\mathrm{g})\end{array}$ \\
\hline \multirow{5}{*}{ I } & 5 & 0 & Normal & $25.0 \pm 1.6$ \\
\hline & 4 & 15 & " & $29.6 \pm 0.8$ \\
\hline & 5 & 30 & $\prime \prime$ & $32.4 \pm 1.3$ \\
\hline & 1 & 90 & $\prime \prime$ & 34.0 \\
\hline & 5 & 180 & " & $38.4 \pm 2.0$ \\
\hline \multirow{4}{*}{ I-L } & 5 & 15 & Normal & $28.1 \pm 1.0$ \\
\hline & 4 & 30 & $?$ & $28.7 \pm 2.5$ \\
\hline & 1 & 90 & Slight central degenerate. (rare) & 35.0 \\
\hline & 5 & 180 & Slight cell hyperplasia & $36.7 \pm 3.1$ \\
\hline \multirow{5}{*}{ II } & 5 & 0 & Slight peripheral vacuol. & $21.3 \pm 1.7$ \\
\hline & 4 & 15 & 11 & $27.8 \pm 0.6$ \\
\hline & 5 & 30 & Slight periph. cell atrophy & $29.2 \pm 1.6$ \\
\hline & 1 & 90 & Peripheral atrophy & 34.0 \\
\hline & 5 & 180 & Central vacuolation & $38.2 \pm 6.2$ \\
\hline \multirow{4}{*}{ II-L } & 5 & 15 & Initial necrosis & $22.8 \pm 3.0$ \\
\hline & 4 & 30 & Initial necrosis & $28.6 \pm 1.9$ \\
\hline & 1 & 90 & Nodular hyperplasia & 33.7 \\
\hline & 5 & 180 & $\begin{array}{l}\text { Nodular hyperplasia with bile } \\
\text { ductule prolif. }\end{array}$ & $34.4 \pm 4.6$ \\
\hline \multirow{5}{*}{ III } & 5 & 0 & Slight diffuse cell vacuol. & $24.0 \pm 2.2$ \\
\hline & 4 & 15 & $\prime \prime$ & $28.8 \pm 0.9$ \\
\hline & 5 & 30 & 11 & $30.2 \pm 0.9$ \\
\hline & 1 & 90 & Diffuse cell vacuolation & 32.2 \\
\hline & 5 & 180 & $\begin{array}{l}\text { Nuclear irregularity and cytoplasm } \\
\text { vacuolation }\end{array}$ & $40.0 \pm 4.7$ \\
\hline \multirow{4}{*}{ III-L } & 4 & 15 & Initial necrosis & $20.8 \pm 2.8$ \\
\hline & 5 & 30 & Initial necrosis & $27.1 \pm 1.9$ \\
\hline & 2 & 90 & $\begin{array}{l}\text { Nodular hyperplasia with bile } \\
\text { ductule prolif. }\end{array}$ & - - \\
\hline & 1 & 180 & Nodular hyperplasia & 28.0 \\
\hline
\end{tabular}

* For details of diets and abbreviation of groups see Materials and Method section 2 and 3.

2) Sulfur contents of the liver.

a. TS: Throughout the feeding period, the TS value for Group I was fairly constant. The values for Group II became smaller in the early stage, reaching a minimum on the 30th day. As for Group III, the TS value decreased slightly in the early stage but the overall tendency was similar to that for Group I (Fig. 1).

b. ASS: The ASS values for the three diet groups are shown in Fig 2. It may be noteworthy that the reduced ASS values demonstrated in Group II was apparent from the early stage of the feeding period. 
and other sulfur compounds of the livers of mice (DDD)

\begin{tabular}{|c|c|c|c|c|}
\hline \multirow{2}{*}{$\begin{array}{l}\text { Liver wt } \\
\text { (wet } \mathrm{g} \text { ) }\end{array}$} & \multirow{2}{*}{$\begin{array}{l}\text { Protein mg } \\
\text { per wet } g \\
\text { of liver }\end{array}$} & \multicolumn{3}{|c|}{$\begin{array}{l}\text { Contents of sulfur compounds (mg) } \\
\text { per wet } \mathrm{g} \text { of liver }\end{array}$} \\
\hline & & TS & ASS & ISS \\
\hline $1.8 \pm 0.1$ & $209 \pm 5$ & $3.27 \pm 0.20$ & $3.13 \pm 0.22$ & $0.67 \pm 0.06$ \\
\hline $2.1 \pm 0.1$ & $207 \pm 10$ & $3.14 \pm 0.22$ & $2.95 \pm 0.17$ & $0.67 \pm 0.03$ \\
\hline $2.0 \pm 0.1$ & $228 \pm 9$ & $2.89 \pm 0.24$ & $2.82 \pm 0.24$ & $0.64 \pm 0.06$ \\
\hline 2.0 & 208 & 2.93 & 2.75 & 0.70 \\
\hline $2.4 \pm 0.1$ & $220 \pm 16$ & $3.13 \pm 0.08$ & $2.85 \pm 0.11$ & $0.72 \pm 0.04$ \\
\hline $1.8 \pm 0.1$ & $198 \pm 4$ & $3.47 \pm 0.23$ & $3.38 \pm 0.38$ & $0.65 \pm 0.07$ \\
\hline $1.5 \pm 0.2$ & $224 \pm 30$ & $2.68 \pm 0.54$ & $2.49 \pm 0.54$ & $0.61 \pm 0.06$ \\
\hline 2.0 & 199 & 3.13 & 2.75 & 0.66 \\
\hline $2.2 \pm 0.2$ & $211 \pm 8$ & $3.12 \pm 0.26$ & $2.98 \pm 0.31$ & $0.68 \pm 0.05$ \\
\hline $1.2 \pm 0.2$ & $181 \pm 9$ & $2.10 \pm 0.39$ & $1.93 \pm 0.24$ & $0.55 \pm 0.04$ \\
\hline $1.7 \pm 0.1$ & $187 \pm 15$ & $2.41 \pm 0.60$ & $2.32 \pm 0.63$ & $0.61 \pm 0.04$ \\
\hline $1.5 \pm 0.1$ & $203 \pm 13$ & $1.85 \pm 0.32$ & $1.78 \pm 0.32$ & $0.56 \pm 0.04$ \\
\hline 1.6 & 187 & 2.55 & 2.50 & 0.56 \\
\hline $1.9 \pm 0.4$ & $201 \pm 7$ & $2.89 \pm 0.33$ & $2.70 \pm 0.25$ & $0.62 \pm 0.04$ \\
\hline $1.2 \pm 0.2$ & $169 \pm 21$ & $3.08 \pm 0.68$ & $2.72 \pm 0.85$ & $0.54 \pm 0.10$ \\
\hline $1.5 \pm 0.1$ & $180 \pm 12$ & $3.29 \pm 0.25$ & $3.21 \pm 0.22$ & $0.49 \pm 0.04$ \\
\hline 1.5 & 140 & 3.42 & 3.13 & 0.44 \\
\hline $1.6 \pm 0.4$ & $188 \pm 21$ & $3.18 \pm 0.54$ & $2.67 \pm 0.59$ & $0.58 \pm 0.07$ \\
\hline $1.6 \pm 0.2$ & $200 \pm 9$ & $3.01 \pm 0.34$ & $2.89 \pm 0.23$ & $0.64 \pm 0.02$ \\
\hline $1.7 \pm 0.1$ & $199 \pm 14$ & $3.37 \pm 0.06$ & $3.19 \pm 0.21$ & $0.65 \pm 0.06$ \\
\hline $1.6 \pm 0.1$ & $204 \pm 13$ & $3.10 \pm 0.49$ & $3.05 \pm 0.49$ & $0.61 \pm 0.05$ \\
\hline 1.8 & 201 & 3.13 & 2.94 & 0.67 \\
\hline $1.9 \pm 0.3$ & $218 \pm 11$ & $3.01 \pm 0.32$ & $2.73 \pm 0.37$ & $0.68 \pm 0.04$ \\
\hline $1.1 \pm 0.2$ & $165 \pm 19$ & $2.37 \pm 0.29$ & $2.28 \pm 0.50$ & $0.51 \pm 0.03$ \\
\hline $1.4 \pm 0.1$ & $184 \pm 4$ & $3.47 \pm 0.16$ & $3.31 \pm 0.13$ & $0.49 \pm 0.04$ \\
\hline$-\quad-$ & -- & $-\quad-$ & $-\quad-$ & $-\quad-$ \\
\hline 1.5 & 228 & 2.83 & 2.75 & 0.68 \\
\hline
\end{tabular}

c. ISS : The ISS values were progressively lower with Diet I, Diet III and Diet II in this order throughout the feeding period (Fig. 3). This tendency appeared to be in association with the decrease in body weight, liver weight and liver protein value.

3) Histopathological changes of the liver.

No histopathological changes were found in the mice of Group I; significant changes were found in those of Groups II and III, as shown in Table 2. In Group II, slight vacuolating degeneration and slight liver cell atrophy in the periphery of acini developed in the early stage (Fig. 5), and atrophy in the peripheral and vacuolation in the central part of acini developed in the later stages (Fig. 6). In Grcup III, a slight diffuse cell 


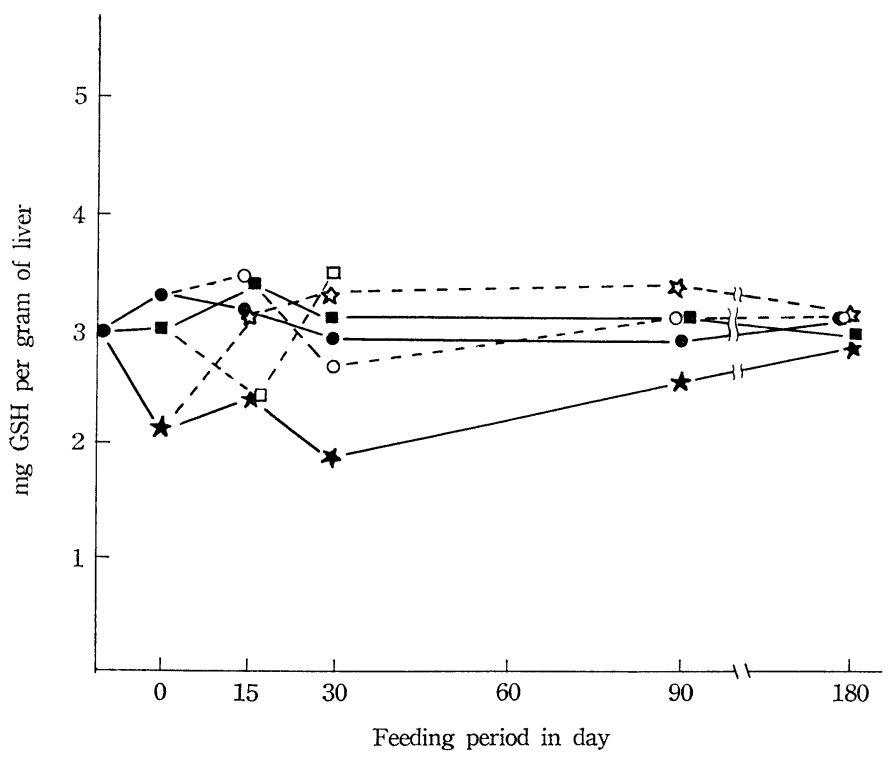

Fig. 1. Effect of experimental diets on total sulfur contents of the liver of mice (DDD)

- Diet I; $\bigcirc---\bigcirc$ Diet I plus luteoskyrin

$\star — \star$ Diet II ;

a- Diet III; $\square---\square$ Diet III plus luteoskyrin

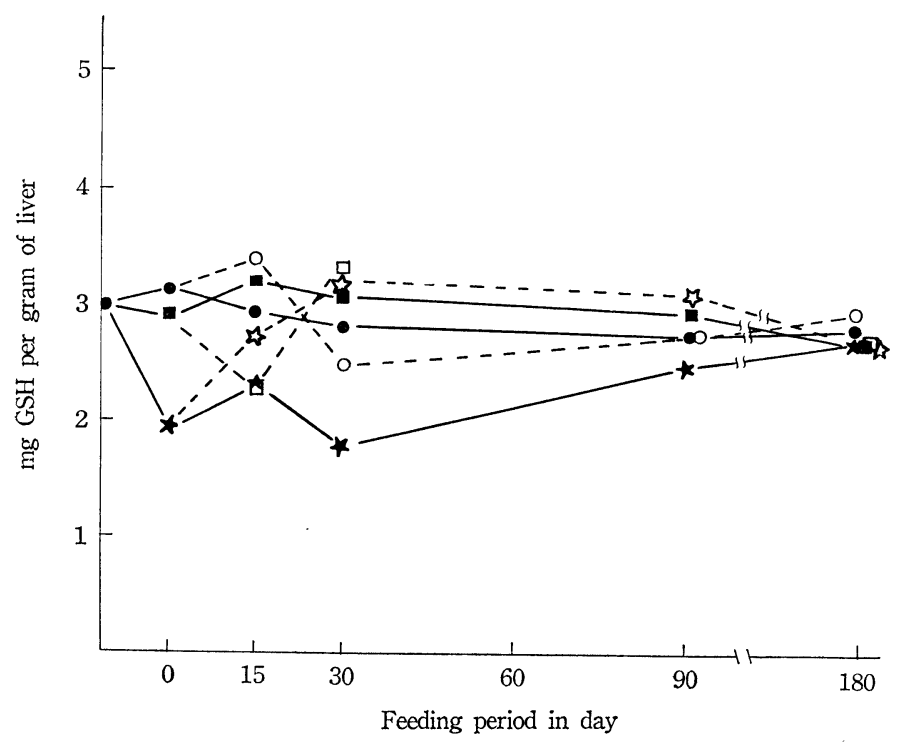

Fig. 2. Effect of experimental diets on acid soluble sulfur contents of the liver of mice (DDD)

- Diet I; O---O Diet I plus luteoskyrin

$\star$ — Diet II ; ‘-- - i Diet II plus luteoskyrin

- Diet III; $\square---\square$ Diet III plus luteoskyrin 


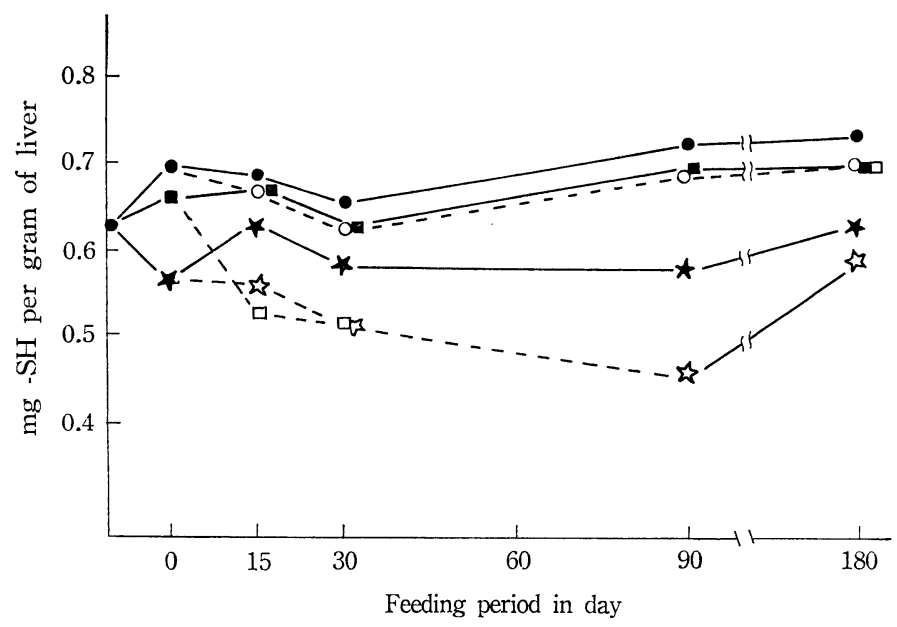

Fig. 3. Effect of experimental diets on acid insoluble sulfur contents of the liver of mice (DDD)

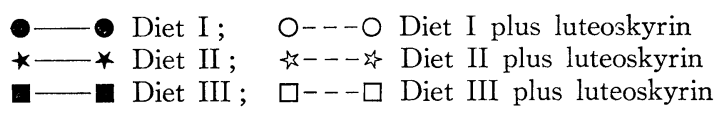

vacuolation developed in the early stage and relatively strong nuclear irregularity and cytoplasm vacuolation were found in the middle and late stages (Figs. 8 and 10). We designate these histological changes of the liver as "carbohydrate food-type degeneration".

\section{Effect of Luteoskyrin Added to the Basic Diets}

\section{1) Body weight, liver weight and liver protein content.}

The figures for body weight, liver weight and protein content for Group I-L decreased in the early stage but restored gradually, and no significant differences between Groups I and I-L were noted. The figures for Groups II-L and III-L markedly decreased from the early stage on and some of the mice died (Table 2 ; for mortality refer to Morooka et al., 1964a). The decreased figures maintained throughout the feeding period. On the 180th day, the figures were considerably variable, some approximated the normal figure while some others were much smaller. The heterogenous responses may reflect the differences in adaptability of mice to the diet containing luteoskyrin.

2) Sulfur contents of the liver.

a. TS: No significant difference in the TS values between Groups I and I-L was exhibited throughout the period. In the mice of Group II-L, the values increased gradually from the beginning, reaching the highest on the 30th day with the DDD strain and on the 90th day with the DDS strain. The values were much larger than those for Group I. The difference between Groups II and II-L was significant till the 90th day, but became insignificant in the later stage. The increase in the values for Group III-L was similar to those for Group II-L, becoming variable from the 30th day. The values were considerably larger than those for Group I, but no significant difference was demonstrable between the Groups III and III-L (Fig. 1).

b. ASS : The change in the ASS values showed a similar tendency to that in the TS values. The values for Group II-L changed gradually from the early stage, becoming 
the highest among the 6 groups on the 30th day with the DDD and on the 90th day with the DDS strain. The difference between Group II and II-L in the ASS values was significant.

A larger influence of luteoskyrin was noted in Group III-L than in II-L. The ASS values for Group III-L were very small on the 15th day but exceeded those for Group III on the 30th day with the DDD strain and on the 90th day with the DDS strain (Fig. 2).

c. ISS: The ISS values for Group I-L were always smaller than those for Group I. Those for Groups II-L and III-L were smaller on the 15th day with the DDD strain, and on the 90th day with the DDS strain, than those for Group II or III. The difference was maintained until the end of the feeding period (Fig. 3).

\section{3) Histopathological changes of the liver.}

Little change was found in the mice of Group I-L in the early stage. On the 90th day and later, degeneration in the centrolobular part of the liver and on the 180th day, slight hyperplasia of the liver cells (Fig. 4) were observed in few cases. The mice of Group II-L showed initial necrosis in the early stage, nodular hyperplasia in the middle stage and hyperplasia with biliary ductules proliferation (Fig. 7) in the late stage. Group III-L showed initial necrosis in the early stage, nodular hyperplasia with biliary ductules proliferation in the middle stage (Fig. 9) and an intensified nodular hyperplasia (Fig. 11) in the late stage.

\section{DISCUSSION}

In the present report is described the correlation between the tumor formation and the change in sulfur contents of the liver of mice. In the low protein diet (Diet II) group, the body weight, liver weight and protein and sulfur contents of the liver decreased.

It appeared that the reduced sulfur contents of the liver of the animals of Group II had resulted from protein deficiency. Therefore, Diet III containing an increased amount of milk casein was included. The diet prevented the reduction in sulfur contents of the liver.

Nevertheless, characteristic histopathological changes were demonstrated in the mice of both Groups II and III. The supplementation of the diet with casein at $23 \%$ did not completely prevent the animals from developing such changes. These changes seemed essentially identical to the hepatic lesions caused by low protein diet (Himsworth, 1945 ; Ericsson, Orrenius and Holm, 1966). Berman (1958) and Sebrell and Hand (1957) described the syndrome by the name of dietary disease ("kwasiorkor" or "marasmus") caused by protein deficiency of diet.

In the present investigation, the semisynthetic diet supplemented with $23 \%$ casein did cause a certain damage to the mouse liver. Such a damage could no longer be attributed entirely to the quantity of protein in the diet. An unbalanced proportion of carbon and nitrogen sources in the diet or lack of a certain essential ingredient in the semisynthetic diet may have been the cause of the changes.

Edward and Westerfeld (1952), Lindan and Work (1953a, b) and Leaf and Neuberger (1947) demonstrated a reduced amount of glutathione in the liver of rats fed on a low protein diet. The results obtained in the present investigation with the low protein diet (Diet II) are in good accordance with their findings. The increase or decrease in sulfur contents of the liver may be partly dependent upon protein contents of the diet. 
Luteoskyrin added to the semisynthetic diet led the liver, damaged by the diet, to develop necrose and even tumors. During the processes of these changes, a marked increase in acid soluble sulfur contents was noted. An increased non-protein sulfhydryl groups were reported by Sugimura and Ono (1957), who determined protein and nonprotein sulfhydryl groups of the tumor-bearing animals.

The phenomenon of increase in the amount of acid soluble sulfur contents of the liver may be an expression of an abnormal metabolism including cell division and growth and oxidation-reduction, metabolic regulation and detoxification by the living body as reported by Barron (1951). In view of the fact that luteoskyrin is a polymer of anthraquinone, the metabolic relationship between sulfur containing substances and quinones in the living body must be also considered.

It was found that tumor develops at a high frequency when luteoskyrin is incorporated into the animal body in which such abnormal metabolism is in progress.

\section{REFERENCES}

Berman, C. (1958): Primary carcinoma of the liver. Adv. Cancer Res., 5, 55-96.

BENNETT, H. S. AND WATTS, R. M. (1958): The cytochemical demonstration and measurement of sulfhydryl groups by azo-aryl mercaptide coupling with special reference to mercury orange. Gen. Cytochem. Method 1, 317-374.

BARRON, E. S. G. (1951): Thiol groups of biological importance. Adv. Enzy., 11, 201-266.

CALCUTT, G. (1964): The sulfphydryl groups of some normal tissues and some animal tumours. Brit. J. Cancer 18, 197-207.

EDWARDS, S. AND WESTERFEI.D, W. W. (1952): Blood and liver glutathione during protein deprivation. Proc. Soc. Exptl. Biol. Med. 79, 57-59.

ERICSSON, J. L. E., ORRENIUS, S. AND HOLM, I. (1966): Alterations in canine liver cells induced by protein deficiency. Ultrastructural and biochemical observations. Exptl. Mol. Pathol. 5, 329-349.

HimswORTH, H. P. (1945): Discussion on the influence of nutritional factors in liver disease. Proc. Roy. Soc. Med. 38, 101-108.

Kobayashi, Y., Uraguchi, K., Sakai, F., Tatsuno, T., Tsukioka, M., Noguchi, Y., Tsunoda, H., Miyake, M., Saito, M., Enomoto, M., Shikata, T. and Ishiko, T. (1959) : Toxicological studies on the yellowed rice by $P$. islandicum Sopp. III. Experimental verification of primary hepatic carcinoma of rats by long term feeding with the fungus-growing rice. Proc. Japan. Acad. 35, 501-506.

KUROIWA, Y. (1953): Researches on glutathione. Part 7. Studies on the iodometric procedure among the determination methods of glutathione on the reduction of oxidized glutathione with $\mathrm{Zn}$ and $\mathrm{H}_{2} \mathrm{~S}$. Japan. Agr. Chem. Soc. 27, 473.

LEAF, G. AND NEUBERGER, A. (1947): The effect of diet on the glutathione content of the liver. Biochem. J. 41, 280-287.

LINDAN, O. AND WORK, E. (1953a): Experimental liver necrosis in rats. 1. Changes in liver, blood and spleen glutathione and ascorbic acid levels in dietetic liver necrosis. Biochem. J., 55, 554-561.

LINDAN, O., AND WORK, E. (1953b) : Experimental liver necrosis in rats. 2. The levels of glutathione and ascorbic acid in livers subjected to acute circulatory congestion in relation to the levels found in dietetic liver necrosis. Biochem. J., 55, 562-566.

Lowry, O. H., Rosebrough, N. J., FARR, A. L. AND RANDAlL, R. J. (1951) : Protein measurement with the folin phenol reagent. J. Biol. Chem. 193, 265-275.

MOROOKA, N. (1956) : Studies on the toxic products of Penicillium islandicum. I. On a toxic pigment produced by surface culture. Japan. J. Med. Sci. Biol. 9, 121-127.

Morooka, N., NAKano, N., MiURA, T., Uchida, N. ANd OKugi, M. (1964a) : Observation 
on development of tumors in the livers of mice by diet containing luteoskyrin (toxic pigment of $P$. islandicum Sopp). Japan. J. Nutrit. 22, 94-101.

Morooka, N., Nakano, N., Miura, T., Uchida, N. and Okugi M. (1964b) : Comparative studies on the enzyme activities in the mice liver cells of normal, regenerating and tumor developed. On the activity of alkaline phosphatase, glutamic oxaloacetic transaminase, cysteine desulfhydrase and $\beta$-glucuronidase. Japan. J. Nutrit. 22, 164-172.

Pecora, L. J. AND Hundley, J. M. (1957) : Nutritional improvement of white polished rice by the addition of lysine and threonine. J. Nutrit. 44, 101-112.

SAKAI, H. AND DAN, K. (1959): Studies on sulfhydryl groups during cell division of sea urchin egg. I. Glutathione. Exptl. Cell Res. 16, 24-41.

SAKAI, H. (1960) : Studies on sulfhydryl groups during cell division of sea urchin egg. II. Mass isolation of the egg cortex and change in its - $\mathrm{SH}$ groups during cell division. J. Biophy. Biochem. Cytol. 8, 603-607.

Sebrell, W. H. AND HAND, D. B. (1957) : Protein malnutrition as a world problem. Amino Acid Malnutrit. Rutgers Univ. Press 47-59.

Shibata, S., TAkido, M. ANd NAKajima, T. (1955): Studies in the metabolic products of fungi. (VII). Paper chromatography of the colouring matters of Penicillum islandicum Sopp. Pharm. Bull., 3, 286-290.

Shibata, S. AND Kitagawa, I. (1956): Metabolic products of fungi. X. The structure of Rubroskyrin and its relation to the structure of Luteoskyrin. Pharm. Bull., 4, 309-313.

SUGIMURA, T. AND ONO, T. (1957): Non-protein and protein sulfhydrl groups in neoplastic tissue. Gann. 48, 77-80.

\section{EXPLANATION OF FIGURES}

Fig. 4: The liver cells on the 180th day of feeding on Diet I-L showing slight pleomorphism and enlarged nuclei in some cells.

Fig. 5: The liver cells on the 90th day of feeding on Diet II showing severe vacuolization of cytoplasm especially in the centrolobular part and a slight shrinkage in the periphery of acinus.

Fig. 6: The liver cells on the 180th day of feeding on Diet II showing vacuolization of cytoplasms both in the cential and peripheral parts of acinus.

Fig. 7: The liver cells on the 180th day of feeding on Diet II-L showing severe destruction of normal histological structure, nodular hyperplasia of liver cells and proliferation of bile ductules with cell infiltration.

Fig. 8: The liver cells on the 90th day of feeding on Diet III showing degeneration of liver cells especially in centrolobular part.

Fig. 9: The liver cells on the 90th day of feeding on Diet III-L showing nodular hyperplasia of liver cells with connective tissue hyperplasia and cell infiltration in surroundings.

Fig. 10: The liver cells on the 180th day of feeding on Diet III showing vacuolation of almost all cells.

Fig. 11: Nodular hyperplasia of the liver on the 180th day of feeding on the Diet III-L showing considerable pleomorphism in the cytoplasm and nucleus. 


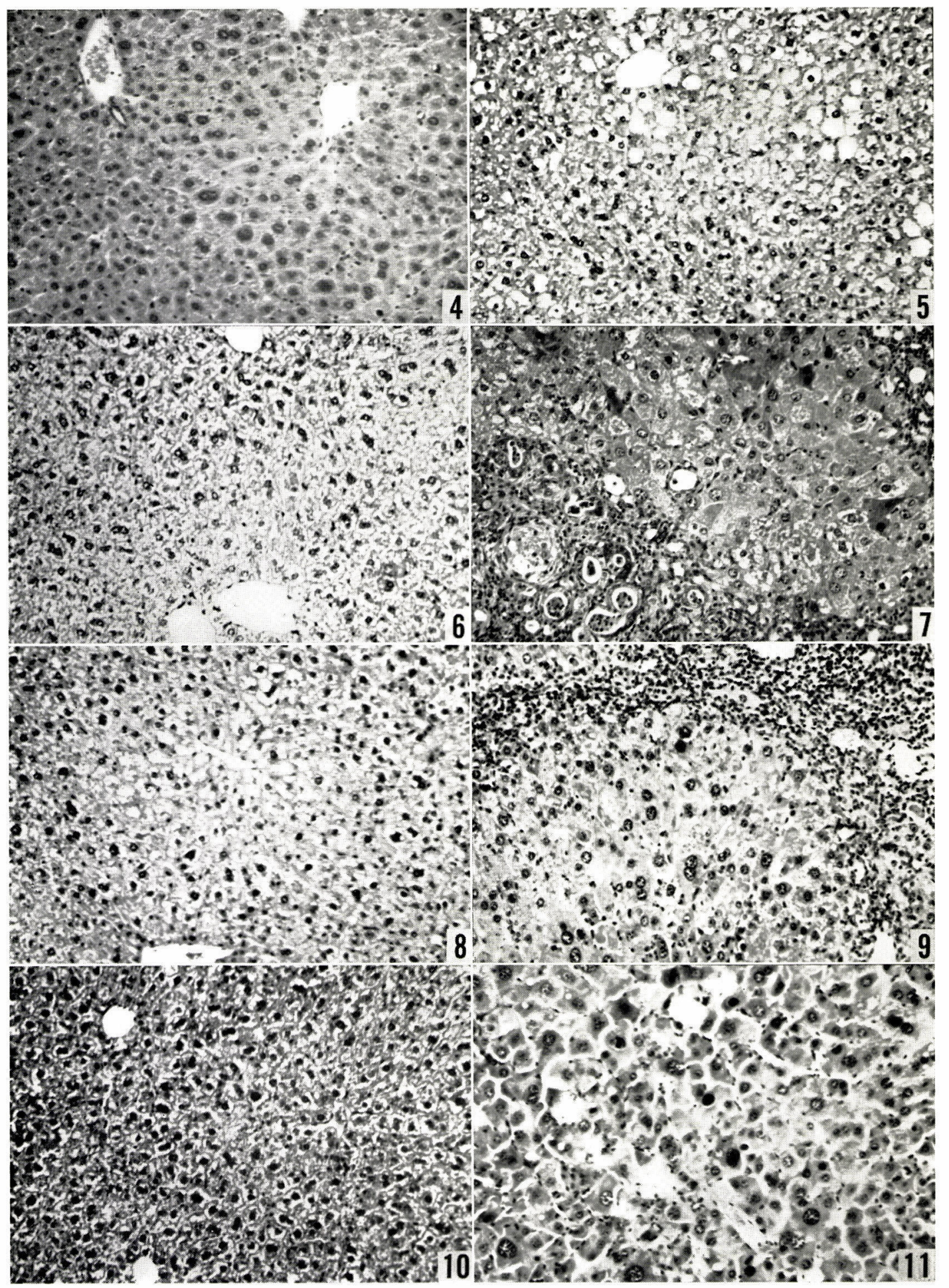

